\title{
Genetic Characterization of the Endangered Kiso Horse Using 31 Microsatellite DNAs
}

\author{
Masaki TAKASU1)*, Nana HIRAMATSU'), Teruaki TOZAKI ${ }^{2)}$, Hironaga ${ }^{1}{ }^{2}$ HKOI $^{2)}$, Takeru NAKAGAWA ${ }^{3)}$, \\ Telhisa HASEGAWA ${ }^{4)}$, Huricha ${ }^{1)}$, Masami MAEDA ${ }^{1)}$, Tetsuma MURASE ${ }^{1)}$ and Harutaka MUKOYAMA ${ }^{5)}$ \\ ${ }^{1)}$ Department of Veterinary Medicine, Faculty of Applied Biological Sciences, Gifu University, 1-1 Yanagido, Gifu 501-1193, Japan \\ ${ }^{2)}$ Laboratory of Racing Chemistry, 1731-2 Tsuruta-cho, Utsunomiya, Tochigi 320-0851, Japan \\ ${ }^{3)}$ The Kiso Horse Conservation Association, 5596-1 Suekawa, Kaida-Kougen, Kiso-cho, Kiso-gun, Nagano 397-0301, Japan \\ ${ }^{4)}$ Equine Research Institute, Japan Racing Association, 321-4 Tokami-cho, Utsunomiya, Tochigi 320-0856, Japan \\ ${ }^{5)}$ Nippon Veterinary and Life Science University, 1-7-1 Kyonan-cho, Musashino, Tokyo 180-8602, Japan
}

(Received 19 January 2011/Accepted 17 September 2011/Published online in J-STAGE 30 September 2011)

ABSTRACT. In order to contribute to conservation of the endangered Kiso horse, we clarified their genetic information using 31 microsatellite DNAs, and genotyped 125 horses, $83 \%$ of the existing breed. First, we clarified the current status of the horses. The horses were confirmed to have experienced rapid loss of population causing a bottleneck, and their effective population size was much smaller than their census size. Moreover, the number of alleles (6.3), observed heterozygosity (0.674), and expected heterozygosity $(0.662)$ were in the same range as other endangered horses all over the world. Therefore, although their inbreeding level was not so severe $\left(\mathrm{F}_{\text {is }}:-0.017\right)$, the Kiso horse is surely one of the endangered. Second, we obtained genetic information of individuals. This information allowed us to understand the genetic distance of individuals, and might help in development of a reproductive strategy concerning the genetic distance between the mating pairs. Moreover, there appeared to be 4 subpopulations of Kiso horse, and this result was in good agreement with their historical background. Third, we confirmed that the parentage test for identification using the 31 microsatellite DNAs was highly reliable (probability of exclusion: 0.999999993). This identification increases the reliability of stud certification, and is also helpful for effective management. Understanding the genetic diversity within the population and the relationships among individuals is important to ensuring effective management for maintenance of genetic variation, and this study may help in conservation of the endangered Kiso horse.

KEY WORDS: conservation, genetic diversity, Japan, Kiso horse, microsatellite DNA.

doi: 10.1292/jvms.11-0025; J. Vet. Med. Sci. 74(2): 161-166, 2012

Each community has unique features based on its historical and cultural background, and the Kiso area, a mountainous region of central Japan, has the Kiso horse (Fig. 1) as a symbol of the local culture. People in the Kiso area treasure the horses as old friends, and have created an original culture centered on horses. Historically, many horses have been kept in the Kiso area, and the area has been wellknown for producing good horses. However, industrialization and motorization have replaced transportation and cultivation systems using horses. The Kiso horse has lost the value as a work animal, and their number decreased to 32 in 1975 [15]. At that time, those concerned about imminent extinction established the Kiso Horse Conservation Association to improve the infrastructure for conservation, such as designation of a natural monument in Nagano Prefecture. Fortunately, many people, not only in the Kiso region but also from outside the region, started to work for conservation of the horse. Moreover, a railway company agreed to conserve the horse, referring to the local culture, and established a conservation farm in 1969-however, the farm was closed in 1997, and the horses were dispersed. Today, the

\footnotetext{
* Correspondence to: Takasu, M., Department of Veterinary Medicine, Faculty of Applied Biological Sciences, Gifu University, 1-1 Yanagido, Gifu 501-1193, Japan. e-mail: takasu@gifu-u.ac.jp
}

(C)2012 The Japanese Society of Veterinary Science number of horses has increased to 149 as a result of their efforts. However, the population of Kiso horses is still small, and the situation is not so optimistic.

In conservation programs, the maintenance of genetic diversity is a major objective; it is essential for a population to be able to face environmental changes in the future and to respond to long-term selection, either natural or artificial,

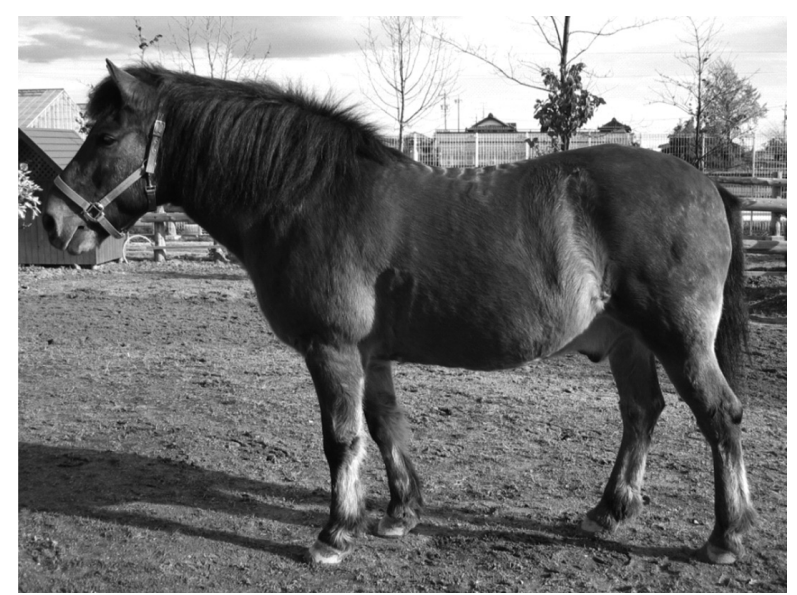

Fig. 1. Appearance of the Kiso horse. The Kiso horse is mediumsized horse with a long body, short legs, and a plump girth, and most are bays. The horse is one of the eight native horses in Japan, and the current population is 149 . 
for traits of economic or cultural interest [12]. Of course, it is better to obtain as many individual data as possible to understand the current status of the population, and precise information about the population helps us plan a conservation strategy considering genetic diversity. In the case of Kiso horses, no one knows the genetic background of the population based on individual data, and therefore we must have a better understanding in order to conserve Kiso horses for generations to come.

The evaluation of genetic diversity of a population would be easier if faster evolving markers were used. Microsatellite DNAs, the few tandem repeat loci, have a high mutation rate, and show high polymorphism and a large number of alleles for a locus [20]. Therefore, microsatellite DNA may prove more informative than classical polymorphisms or sequence data for assessing the structure of the population and determining the relationship within a population $[3,14]$. For this reason, population genetics and conservation biology often use microsatellite DNAs to characterize a population $[11,14]$, and so we clarified genetic information of Kiso horses using 31 microsatellite DNAs in order to contribute to their conservation in terms of genetic diversity in this study.

Table 1. Microsatellite DNAs analyzed in this study

\begin{tabular}{|c|c|c|c|}
\hline Microsatellite & Chromosome & $\begin{array}{c}\text { Sequence position } \\
\text { on equCab2 of } \\
\text { BroadInstitute }\end{array}$ & $\begin{array}{l}\text { Accession } \\
\text { number } \\
\text { of NCBI }\end{array}$ \\
\hline AHT4 & chr24 & 23415722 & Y07733 \\
\hline AHT5 & chr08 & Unknown & Y07732 \\
\hline ASB002 & $\operatorname{chr} 15$ & 54612720 & X93516 \\
\hline ASB017 & chr02 & 30601026 & X93531 \\
\hline ASB023 & chr03 & 79279213 & X93537 \\
\hline CA425 & $\operatorname{chr} 28$ & 43085659 & U67406 \\
\hline HMS3 & chr09 & 16895938 & X74632 \\
\hline HMS6 & chr04 & 7229293 & X74635 \\
\hline HMS7 & chr01 & 162381813 & X74636 \\
\hline HTG4 & chr09 & 1497830 & AF169165 \\
\hline HTG10 & $\operatorname{chr} 21$ & 17139130 & AF169294 \\
\hline LEX3 & $\operatorname{chrX}$ & 110524114 & AF075607 \\
\hline LEX033 & chr04 & 59500074 & AF075635 \\
\hline TKY19 & $\operatorname{chr} 18$ & 539493 & $\mathrm{AB} 048330$ \\
\hline TKY28 & chr06 & 66838196 & $\mathrm{AB} 048335$ \\
\hline TKY279 & chr16 & 6632374 & AB033930 \\
\hline TKY287 & $\operatorname{chr} 17$ & 4470525 & AB033938 \\
\hline TKY294 & $\operatorname{chr} 27$ & 19565304 & $\mathrm{AB} 034603$ \\
\hline TKY297 & chr01 & 62748186 & $\mathrm{AB} 034606$ \\
\hline TKY301 & $\operatorname{chr} 23$ & 21066889 & $\mathrm{AB} 034610$ \\
\hline TKY312 & chr06 & 17320169 & $\mathrm{AB} 034621$ \\
\hline TKY321 & chr20 & 61778074 & AB034629 \\
\hline TKY325 & chr29 & 27565193 & AB044826 \\
\hline TKY333 & $\operatorname{chr} 28$ & 2475777 & $\mathrm{AB} 044834$ \\
\hline TKY337 & chr04 & 29877413 & AB044838 \\
\hline TKY341 & chr16 & 81718708 & $\mathrm{AB} 044842$ \\
\hline TKY343 & chr11 & 12997597 & $\mathrm{AB} 044844$ \\
\hline TKY344 & chr05 & 92501364 & AB044845 \\
\hline TKY374 & chr01 & 98084756 & $\mathrm{AB} 044874$ \\
\hline TKY394 & $\operatorname{chr} 24$ & 33978924 & AB048299 \\
\hline VHL20 & chr30 & 18793939 & X75970 \\
\hline
\end{tabular}

\section{MATERIALS AND METHODS}

We collected blood samples from 125 horses using EDTA as an anticoagulant, from April 2008 to October 2009. The registered number of Kiso horses was 149, and we obtained samples from $83 \%$ of the whole breed. The horses were 12 males, 96 females, and 17 geldings, and the average age was 11.5 years, ranging from 1 to 29 years. Genomic DNA was extracted using a Wizard ${ }^{\circledR}$ Genomic DNA Purification Kit (Promega, Madison, WI, U.S.A.) according to the protocol of the manufacturer.

We employed the 31 microsatellites used for parentage testing of racing horses in Japan (Table 1). These markers were amplified by multiplex PCR according to Kakoi et al. [17] and Tozaki et al. [32] with a minor modification. Since the amplification in TKY337 including a null allele was low when we used the original primer, this marker was analyzed alone by the following primers: forward primer, 5'-TAAGACTCAAGAGGTCAATC-3', reverse primer, 5' TACTCTCCAACTCTTCCACT-3'. The information about primers used here and PCR conditions is available on request. We electrophoresed PCR products using the 3130xl Genetic Analyzer (Applied Biosystems, Carlsbad, CA, U.S.A.), genotyped each marker using the GeneMapper Software ${ }^{\circledR}$ (Applied Biosystems), and confirmed the reliability of the present genotypes compared with the published data of the Horse Comparison Test from the International Society for Animal Genetics (ISAG). To confirm that each marker does not show linkage disequilibrium, we calculated D' using SNPAlyze ver 8.0 (Dynacom, Chiba, Japan). No D' was $>0.8$, and this result confirmed that there is no strong linkage disequilibrium between each marker.

In this study, we estimated the number of alleles (NA), allelic frequency, observed heterozygosity (Ho), expected heterozygosity $(\mathrm{He})$, and inbreeding coefficient $\left(\mathrm{F}_{\mathrm{IS}}\right)$ according to Weir and Cockerham [34] of the respective markers using GENEPOP version 4.0.10 [25, 26], and compared the average NA, Ho, and He with those of other endangered horses listed in the WWL-DAD (Table 2). We also determined the polymorphic information content (PIC) using Cervus 3.0 [19], and estimated the probability of exclusion (PE) according to Jamieson's formula [16].

To understand the genetic distance of individuals $\left(D_{\mathrm{ps}}\right)$, we calculated the proportion of shared allele among individuals using Microsatellite Analyzer 4.05 [6], and visualized the $\mathrm{D}_{\mathrm{ps}}$ by a neighbor-joining $(\mathrm{NJ})$ analysis using NEIGHBOR implemented in PHYLIP version 3.69 [10]. To estimate population structure, we performed Bayesian analysis using Structure ver 2.3.3 [24], and carried out the analysis of five replicate runs for the number of population $(\mathrm{K})$ between 1 and 10. For each replication, 30,000 iterations were used. The best $K$ value was estimated based on $\Delta K$ [9] implemented in Structure Harvester [8].

Since the two-phased model of mutation (TPM) provides a good description of the mutation process of simple sequence repetition, including microsatellite DNA [7], we examined the existence of a genetic bottleneck using BOT- 
Table 2. Diversity of microsatellites in native horses listed in the WWL-DAD*

\begin{tabular}{|c|c|c|c|c|c|c|c|}
\hline Breed & Category* & Population size* & $\begin{array}{l}\text { Mean number } \\
\text { of alleles }\end{array}$ & $\begin{array}{c}\text { Observed } \\
\text { heterozygosities }\end{array}$ & $\begin{array}{c}\text { Expected } \\
\text { heterozygosities }\end{array}$ & Country & Reference \\
\hline Kiso** & Critical & 50 우, 5 이 $^{x}$ & 6.3 & 0.67 & 0.66 & Japan & \\
\hline $\mathrm{Kiso}^{* * *}$ & Critical & 50 우, 5 지 & 3.8 & 0.68 & 0.69 & Japan & Kakoi et al. (2007) \\
\hline Kiso $* * * *$ & Critical & 50 우, 5 이 & 4.8 & 0.66 & - & Japan & Tozaki et al. (2003) \\
\hline Misaki & Critical & 40 우, 25 이 & 3.4 & 0.52 & 0.51 & Japan & Kakoi et al. (2007) \\
\hline Misaki & Critical & 40 우, 25 지 & 3 & 0.43 & - & Japan & Tozaki et al. (2003) \\
\hline Noma & Critical & 30 우, 10 지 & 3.6 & 0.67 & 0.59 & Japan & Kakoi et al. (2007) \\
\hline Noma & Critical & 30 우, 10 지 & 3.7 & 0.61 & - & Japan & Tozaki et al. (2003) \\
\hline Yonaguni & Critical & 60 우, 5 지 궁 & 4.1 & 0.62 & 0.63 & Japan & Kakoi et al. (2007) \\
\hline Yonaguni & Critical & 60 우, 5 이 & 3.8 & 0.69 & - & Japan & Tozaki et al. (2003) \\
\hline Lipizzano & Critical & 54 우, 6 지 & 4.7 & 0.64 & 0.61 & Italy & Achmann et al. (2004) \\
\hline Lipican & Critical & 48 우, 14 국 & 5.3 & 0.66 & 0.63 & Slovakia & Achmann et al. (2004) \\
\hline Tokara pony & Critical-maintained & 60 우, 50 이 & 2.6 & 0.44 & 0.43 & Japan & Kakoi et al. (2007) \\
\hline Tokara pony & Critical-maintained & 60 우, 50 근 & 2.1 & 0.34 & - & Japan & Tozaki et al. (2003) \\
\hline Tsushima & Critical-maintained & 20 우, 5 지 & 4.6 & 0.66 & 0.65 & Japan & Kakoi et al. (2007) \\
\hline Tsushima & Critical-maintained & 20 우, 5 지 & 4.1 & 0.64 & - & Japan & Tozaki et al. (2003) \\
\hline Lipizzaner & Critical-maintained & 100 우, 35 기 & 6.2 & 0.66 & 0.64 & Austria & Achmann et al. (2004) \\
\hline Skyros pony & Critical-maintained & 53 우, 26 지 & 5.9 & - & - & Greek & Bömcke et al. (2009) \\
\hline Sorraiana & Critical-maintained & 60 우, 10 지 & 3.3 & 0.45 & 0.47 & Portugal & Luís et al. (2007) \\
\hline Jaca Navarra & Endangered & 240,10 वे & 7.3 & 0.77 & 0.74 & Spain & Solis et al. (2005) \\
\hline Knabstrupper & Endangered & 170 & 7.3 & 0.71 & 0.77 & Denmark & Thirstrup et al. (2008) \\
\hline Lipicanac & Endangered & 400,200 우, 97 구 & 5.2 & 0.67 & 0.65 & Croatia & Achmann et al. (2004) \\
\hline Pottoka & Endangered & 400 우, 170 이 & 8.1 & 0.75 & 0.76 & Spain & Solis et al. (2005) \\
\hline Frederiksborgheste & Endangered-maintained & 230 & 5.3 & 0.66 & 0.65 & Denmark & Thirstrup et al. (2008) \\
\hline Garrano & Endangered-maintained & 1000 우, 30 중 & 10.2 & 0.73 & 0.75 & Portugal & Morais et al. (2004) \\
\hline Lipicai & Endangered-maintained & 322 우, 24 지 & 5.8 & 0.71 & 0.68 & Hungary & Achmann et al. (2004) \\
\hline
\end{tabular}

* World Watch List for Domestic Animal Diversity, 3rd ed. by FAO. ** Rresults of our study. *** Twelve horses were sampled to study the formation process of native Japanese horses. **** Twenty-one horses were sampled to study the phylogenetic relationship.

TLENECK version 1.2.02 [5] according to the TPM model. A population that has experienced a bottleneck shows a higher Ho than He under the Hardy-Weinberg equilibrium, and we performed the Wilcoxon signed-rank test to detect the deviation from the equilibrium. $P<0.05$ was considered to be significant.

Effective population size $(\mathrm{Ne})$ was calculated based on census data, the numbers of males/females (without geldings), in the current population. Furthermore, Ne based on genetic data, Ho and He, was also calculated as follows [29]:

$$
\mathrm{Ne}=1 /\{2(\mathrm{Ho}-\mathrm{He}) / \mathrm{He}\}+1 /[2\{(\mathrm{Ho}-\mathrm{He}) / \mathrm{He}+1\}+1]
$$

\section{RESULTS}

Table 3 shows NA, Ho, He, FIs, PIC, and PE for each microsatellite DNA. NA was 6.3 on average, ranging from 4 to 9 . Ho averaged 0.674 , ranging from 0.288 in $T K Y 333$ to 0.824 in HMS6, TKY343, and TKY394. He averaged 0.662 , ranging from 0.299 in $T K Y 333$ to 0.810 in TKY19. $\mathrm{F}_{\mathrm{IS}}$ averaged -0.017 , ranging from -0.092 in HMS6 to 0.244 in TKY312. PIC was 0.619 on average, ranging from 0.285 in $T K Y 333$ to 0.778 in TKY19. PE was 0.441 on average, ranging from 0.161 in TKY344 to 0.619 in CA425, and the combined PE of the 31 microsatellite DNAs was 0.999999993. Moreover, the confirmable records of 32 parentages were consistent with the results of parentage testing using the microsatellite DNAs.

We were able to obtain $D_{\mathrm{ps}}$ among individual horses, and visualized the $D_{p s}$ using a NJ tree (Fig. 2). In the Bayesian analysis, the structure shown in Fig. 3 demonstrated that the Kiso horse has 4 subpopulations $(\mathrm{K}=4, \Delta \mathrm{K}=70.394)$.

The probability value in the Wilcoxon signed-rank test was 0.032 , and deviated from the Hardy-Weinberg equilibrium according to the TPM. Therefore, this result confirmed that the Kiso horse genetically experienced a bottleneck in the past. Moreover, the Nes based on the census data and genetic data were 45.8 and 28.1, respectively.

\section{DISCUSSION}

When we look at native horses all over the world, most of them are on the verge of extinction [13]. The Kiso horse experienced rapid loss of the population causing a bottleneck, which we confirmed here, and is categorized as one of such endangered breeds $[27,28]$. In fact, the Nes (45.8 and 28.1) were much smaller than their census size, and the difference between the $\mathrm{Ne}$ based on census data (45.8) and $\mathrm{Ne}$ based on genetic data (28.1) suggested that there was a selection bias for specific stallions. Moreover, comparison of the NA, Ho, and He of the Kiso horse with other engendered breeds showed that the genetic diversity of the horse (NA, $\mathrm{Ho}$, and $\mathrm{He}$ on average were $6.3,0.674$, and 0.662 , respectively) was in the middle level among the others listed in the WWL-DAD (ranging from 2.1-10.2 for NA, 0.34-0.77 for Ho, and $0.43-0.77$ for $\mathrm{He}$ ) [1, 2, 18, 21, 22, 30, 31, 33]. Consequently, although the inbreeding level in the horse might not be so severe $\left(F_{i s}:-0.017\right)$, these facts suggest that the Kiso horse is surely one of the endangered breeds.

The horse is still symbolic and very important for identi- 
Table 3. The number of alleles, observed heterozygosity, expected heterozygosity, polymorphic information content, and probability of exclusion in each microsatellite locus

\begin{tabular}{|c|c|c|c|c|c|c|}
\hline Markers & $\begin{array}{l}\text { Number of } \\
\text { alleles }\end{array}$ & $\begin{array}{c}\text { Observed } \\
\text { heterozygosity }\end{array}$ & $\begin{array}{c}\text { Expected } \\
\text { heterozygosity }\end{array}$ & $\mathrm{F}_{\mathrm{IS}} * *$ & $\begin{array}{c}\text { Polymorphic } \\
\text { information content }\end{array}$ & $\begin{array}{l}\text { Probability of } \\
\text { exclusion }\end{array}$ \\
\hline AHT4 & 6 & 0.712 & 0.658 & -0.082 & 0.623 & 0.443 \\
\hline AHT5 & 6 & 0.664 & 0.629 & -0.056 & 0.555 & 0.349 \\
\hline ASB2 & 8 & 0.712 & 0.699 & -0.018 & 0.658 & 0.478 \\
\hline ASB17 & 6 & 0.392 & 0.429 & 0.086 & 0.405 & 0.251 \\
\hline ASB23 & 6 & 0.576 & 0.577 & 0.001 & 0.509 & 0.317 \\
\hline CA425 & 7 & 0.800 & 0.805 & 0.007 & 0.776 & 0.619 \\
\hline HMS3 & 6 & 0.800 & 0.770 & -0.039 & 0.727 & 0.541 \\
\hline HMS6 & 6 & 0.824 & 0.755 & -0.092 & 0.716 & 0.537 \\
\hline HMS7 & 6 & 0.696 & 0.647 & -0.077 & 0.603 & 0.416 \\
\hline HTG4 & 4 & 0.536 & 0.510 & -0.051 & 0.471 & 0.295 \\
\hline HTG10 & 7 & 0.776 & 0.745 & -0.041 & 0.706 & 0.525 \\
\hline LEX3* & 6 & 0.719 & 0.736 & 0.024 & 0.695 & 0.512 \\
\hline LEX33 & 6 & 0.752 & 0.699 & -0.076 & 0.643 & 0.444 \\
\hline TKY19 & 7 & 0.776 & 0.810 & 0.042 & 0.778 & 0.616 \\
\hline TKY28 & 6 & 0.784 & 0.730 & -0.074 & 0.694 & 0.516 \\
\hline TKY279 & 6 & 0.696 & 0.655 & -0.062 & 0.592 & 0.396 \\
\hline TKY287 & 7 & 0.760 & 0.761 & 0.001 & 0.717 & 0.530 \\
\hline TKY294 & 4 & 0.456 & 0.440 & -0.036 & 0.388 & 0.222 \\
\hline TKY297 & 7 & 0.768 & 0.788 & 0.026 & 0.759 & 0.598 \\
\hline TKY301 & 6 & 0.696 & 0.689 & -0.011 & 0.647 & 0.460 \\
\hline TKY312 & 5 & 0.520 & 0.687 & 0.244 & 0.620 & 0.409 \\
\hline TKY321 & 5 & 0.632 & 0.615 & -0.029 & 0.541 & 0.338 \\
\hline TKY325 & 9 & 0.768 & 0.713 & -0.077 & 0.675 & 0.496 \\
\hline TKY333 & 5 & 0.288 & 0.299 & 0.038 & 0.285 & 0.164 \\
\hline TKY337 & 5 & 0.704 & 0.678 & -0.039 & 0.622 & 0.422 \\
\hline TKY341 & 7 & 0.592 & 0.631 & 0.062 & 0.593 & 0.412 \\
\hline TKY343 & 9 & 0.824 & 0.796 & -0.035 & 0.765 & 0.597 \\
\hline TKY344 & 5 & 0.344 & 0.317 & -0.087 & 0.290 & 0.161 \\
\hline TKY374 & 7 & 0.776 & 0.743 & -0.044 & 0.706 & 0.529 \\
\hline TKY394 & 9 & 0.824 & 0.758 & -0.087 & 0.727 & 0.559 \\
\hline VHL20 & 6 & 0.720 & 0.756 & 0.048 & 0.714 & 0.531 \\
\hline Mean & 6.3 & 0.674 & 0.662 & -0.017 & 0.619 & 0.441 \\
\hline
\end{tabular}

* LEX3 is an $\mathrm{x}$-linked marker, and the value is estimated in the female population. $* * \mathrm{~F}_{\mathrm{IS}}$ : Coefficient of inbreeding estimated by Weir and Cockerham.

fying the culture of each area in the world. Therefore, some efforts have made by breeder associations or governments to conserve native horses based on scientific ways [4, 13, 27]. Similarly, we started to work with the Kiso Horse Conservation Association to create a management program for conservation, and studied the genetic diversity of the Kiso horse in this study. As a result, we acquired two valuable pieces of information, the genetic information and reliable identification of individuals, for conservation of the horse.

We obtained genetic information on individuals accounting for $83 \%$ of the whole breed, and were able to calculate the $\mathrm{D}_{\mathrm{ps}}$. This information, simply visualized using a NJ tree, might help us to develop a reproductive strategy concerning genetic distance between the mating pairs. Moreover, the Bayesian analysis suggested that the population of Kiso horses contained 4 genetic components; most of the horses categorized as subpopulation I (Red) had belonged to the farm established by a railway company or were their offspring, horses categorized as subpopulation II (Green) were kept by a private equestrian club in Kiso Town, and horses categorized as subpopulations III (Blue) and IV (Yellow) were the lineage of stallions belonging to The Kiso Horse Conservation Association. This result was in good agreement with the historical background of the horses. Historically, each horse owner or group of owners has individually tended to deal with the conservation issue, and so they might have had to mate horses within a small horse group, because of the limited number of horses. Our results might prove this tendency of mating genetically, and highlight one of the problems that accelerated the inbreeding level of the horse. Of course, although we admire the determination and efforts of owners for the conservation, the current situation of the horse seems to be a bit beyond their individual efforts now, and we would like to discuss this issue with all of horse owners in order to conserve the genetic diversity of the Kiso horse.

Reliable identification is important for effective management of the population [12]. PE based on the combined 31 microsatellites was 0.999999993 , suggesting the reliability of a parentage test for identification of the Kiso horse as well as racing horses. This identification makes stud certification highly reliable and helps effective management for mating as well as obtaining genetic data for individuals. Hence, continuous typing of microsatellite DNAs for newborn foals may encourage appropriate management to conserve their genetic diversity, and we must therefore continue this analysis for conservation. 


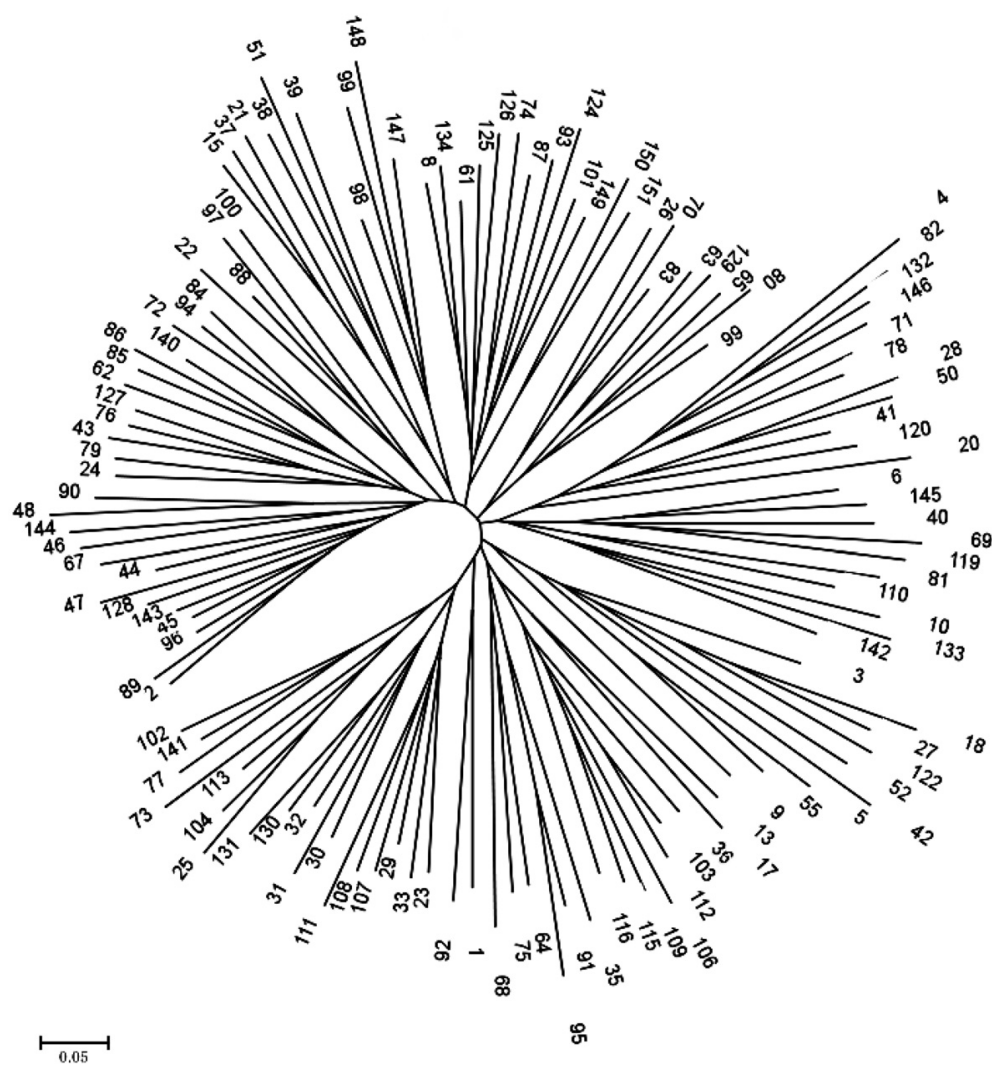

Fig. 2. The neighbor-joining tree based on the genetic distance estimated with the proportion of shared alleles.

In this study, we characterized genetics of the Kiso horse based on microsatellite DNAs in order to contribute to conservation. This horse is a symbol of the culture in the Kiso area, which involves a close relationship between men and horses, and extinction of the horse means loss of a piece of our culture, leading to cultural uniformity and a crisis in regional identity. Therefore, awareness of the roles and values of genetic resources and concern for their rapid loss must be translated into effective action at the local, national, and global levels [27] in order to conserve biodiversity as

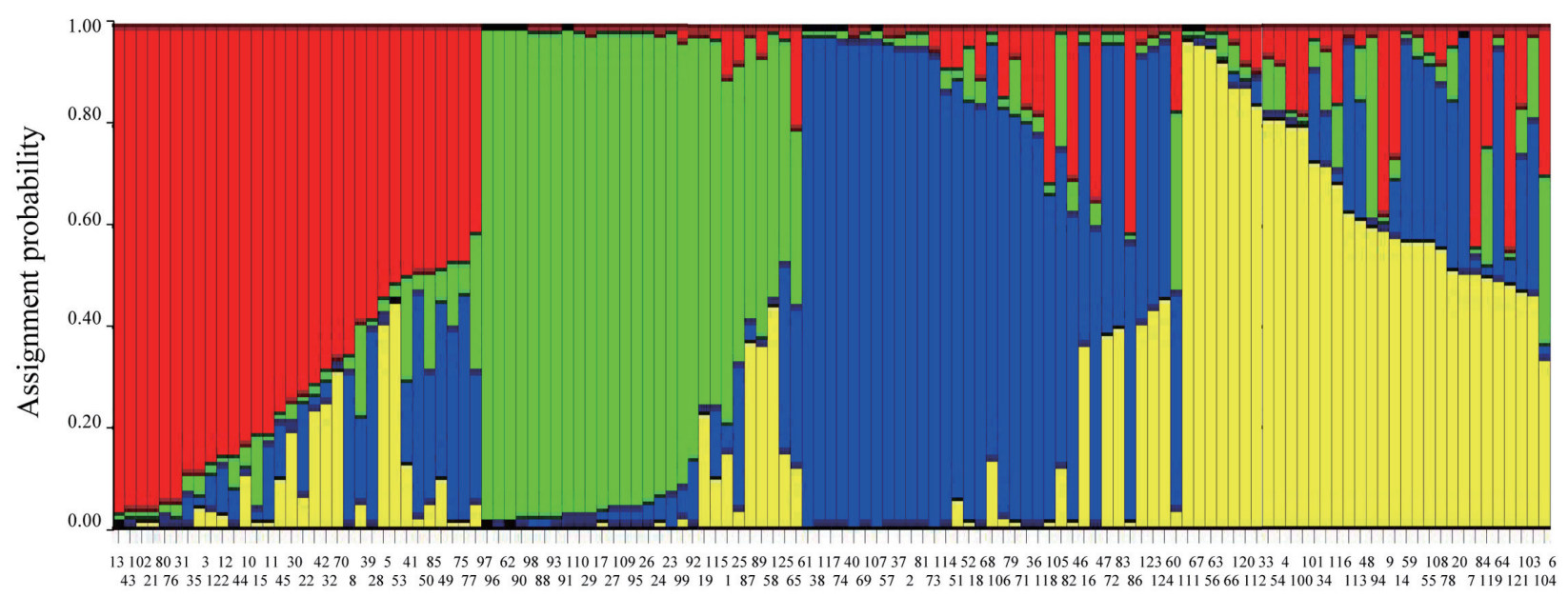

Identification number of the horses

Fig. 3. The STRUCTURE suggested that the Kiso horse has 4 subpopulations: subpopulation I (Red), subpopulation II (Green), subpopulation III (Blue), and subpopulation IV (Yellow). $K=4, \Delta K=70.394$. 
well as cultural diversity.

ACKNOWLEDGMENTS. We gratefully acknowledge the contribution of the horse owners. We also thank Dr. Shuichi Matsumura of Gifu University for his valuable suggestions. This work was supported in part by a Grant-in-Aid from Kiso Town.

\section{REFERENCES}

1. Achmann, R., Curik, I., Dovc, P., Kavar, T., Bodo, I., Habe, F., Marti, E., Sölkner, J. and Brem, G. 2004. Microsatellite diversity, population subdivision and gene flow in the Lipizzan horse. Anim. Genet. 35: 285-292.

2. Bömcke, E. and Gengler, N. 2009. Combining microsatellite and pedigree data to estimate relationship among Skyros ponies. J. Appl. Genet. 50: 133-143.

3. Bowcock, A. M., Ruiz-Linares, A., Tomfohrde, J., Minch, E., Kidd, J. R. and Cavalli-Sforza, L. L. 1994. High resolution of human evolutionary trees with polymorphic microsatellites. Nature 368: 455-457.

4. Choi, S. K., Cho, C. Y., Yeon, S. H., Cho, B. W. and Cho, G. J. 2008. Genetic characterization and polymorphisms for parentage testing of the Jeju horse using 20 microsatellite loci. J. Vet. Med. Sci. 70: 1111-1115.

5. Cornuet, J. M. and Luikart, G. 1996. Description and power analysis of two testes for detecting recent population bottlenecks from allele frequency data. Genetics 144: 2001-2014.

6. Dieringer, D. and Schlotterer, C. 2003. Microsatellite analyzer (MSA): a platform independent analysis tool for large microsatellite data sets. Mol. Ecol. Notes 3: 167-169.

7. Di Rienzo, A., Peterson, A. C., Garza, J. C., Valdes, A. M., Slatkin, M. and Freimer, N. B. 1994. Mutational processes of simple-sequence repeat loci in human populations. Proc. Natl. Acad. Sci. U.S.A. 91: 3166-3170.

8. Earl, D. A. 2001. Structure harvester v0.6.1. [cited 2010, Dec, 20] Available at http://taylor0.biology.ucla.edu/struct_harvest/

9. Evanno, G., Regnaut, S. and Goudget, J. 2005. Detecting the number of clusters of individuals using the software structure: a simulation study. Mol. Ecol. 14: 2611-2620.

10. Felsenstein, J. 1989. PHYLIP—Phylogeny inference package (version 3.2). Cladistics 5: 164-166.

11. Fernández J. F., Villanueva, B., Pong-Wong, R. and Toro, M. Á. 1989. Efficiency of the use of pedigree and molecular marker information in conservation programs. Genetics 170: 1313-1321.

12. Frankham, R., Ballou, J. D. and Briscoe, D. A. 2009. Genetic diversity. pp. 41-65. In: Introduction to Conservation Genetics. 2nd ed., Cambridge University Press, U.K.

13. Giacomoni, E. H., Fernandez-Stolz, G. P. and Freitas, T. R. O. 2008. Genetic diversity in the Pantaneiro horse breed assessed using microsatellite DNA markers. Genet. Mol. Res. 7: 261-270.

14. Goldstein, D. B., Linares, A. R., Cavalli-Sforza, L. L. and Feldman, M. W. 1995. An evaluation of genetic distances for use with microsatellite loci. Genetics 139: 463-471.

15. Ito, M. 1996. Prosperity and decline of Kiso horse. pp. 13-89. In: Life with Kiso Horses, Kaida Village and Kiso Horse Conservation Association, Kaida (in Japanese).

16. Jamieson, A. and Taylor, S. C. S. 1997. Comparisons of three probability formulae for parentage exclusion. Anim. Genet. 28: 397-400.

17. Kakoi, H., Nagata, S. and Kurosawa, M. 2001. DNA typing with 17 microsatellites for parentage verification of racehorses in Japan. Anim. Sci. J. 72: 453-460.

18. Kakoi, H., Tozaki, T. and Gawahara, H. 2007. Molecular analysis using mitochondrial DNA and microsatellites to infer the formation process of Japanese native horse populations. Biochem. Genet. 45: 375-395.

19. Kalinowski, S. T., Taper, M. L. and Marshall, T. C. 2007. Revising how the computer program CERVUS accommodates genotyping error increases success in paternity assignment. Mol. Eco. 16: 1099-1106.

20. Luikart, G., Sherwin, W. B., Steele, B. M. and Allendorf, F. W. 1998. Usefulness of molecular markers for detecting population bottlenecks and monitoring genetic change. Mol. Eco. 7: 963-974.

21. Luís, C., Cothran, E. G. and Oom, M. M. 2007. Inbreeding and genetic structure in the endangered Sorraia horse breed: Implications for its conservation and management. J. Hered. 98: 232-237.

22. Morais, J., Oom, M. M., Malta-Vacas, J. and Luís, C. 2004. Genetic structure of an endangered Portuguese semiferal pony breed, the Garrano. Biochem. Genet. 43: 347-364.

23. Nozawa, K., Shotake, T. and Kawamoto, Y. 1998. Phylogenetic relationships among Japanese native and alien horses estimated by protein polymorphisms. J. Equine Sci. 2: 53-69.

24. Pritchard, J. K., Stephens, M. and Donelly, P. 2000. Inference of population structure using multilocus genotype data. Genetics 155: 945-959.

25. Raymond, M. and Rousset, F. 1995. GENEPOP (version 1.2): population genetics software for exact tests and ecumenicism. J. Hered. 86: 248-249.

26. Rousset, F. 2008. Genepop'007: a complete reimplementation of the Genepop software for Windows and Linux. Mol. Ecol. Resources 8: 103-106.

27. Scherf, B. D. 2000. Using WWL-DAD: 3. pp. 1-36. In: World Watch List of Domestic Animal Diversity, 3rd ed., Food and Agriculture Organization of the United Nations, Rome.

28. Scherf, B. D. 2000. Farm animal genetic resources. pp. 37-646. World Watch List of Domestic Animal Diversity, 3rd ed., Food and Agriculture Organization of the United Nations, Rome.

29. Schwartz, M. K., Tallom, D. A. and Luikart, G. 1998. Review of DNA-based census and effective population size estimators. Anim. Conserve. 1: 293-299.

30. Solis, A., Jugo, B. M., Mériaux, J. C., Iriondo, M., Mazón, L. I., Aguirre, A. I., Vicario, A. and Estomba, A. 2005. Genetic diversity within and among four South European native horse breeds based on microsatellite DNA analysis: Implication for conservation. J. Hered. 96: 670-678.

31. Thirstrup, J. P., Pertoldi, C. and Loeschcke, V. 2008. Genetic analysis, breed assignment and conservation priorities of three native Danish horse breeds. Anim. Genet. 39: 496-505.

32. Tozaki, T., Kakoi, H., Mashima, S., Hirota, H., Hasegawa, T., Ishida, N., Miura, N., Choi-Miura, N. M. and Tomita, M. 2001. Population study and validation of paternity testing for thoroughbred horses by 15 microsatellite loci. J. Vet. Med. Sci. 63: 1191-1197.

33. Tozaki, T., Takezaki, N., Hasegawa, T., Ishida, N., Kurosawa, M., Tomita, M., Saitou, N. and Mukoyama, H. 2003. Microsatellite variation in Japanese and Asian horses and their phylogenetic relationship using a European horse outgroup. J. Hered. 94: 374-380.

34. Weir, B. S. and Cockerham, C. C. 1984. Estimating F-statistics for the analysis of population structure. Evolution 38: 1358-1370. 